\title{
MODEL REVIEW OF INFORMAL RULEMAKING: RECOMMENDATION 74-4 OF THE ADMINISTRA- TIVE CONFERENCE OF THE UNITED STATES
}

The future effectiveness of informal rulemaking may hang in the balance of a currently raging debate over the proper scope of preenforcement judicial review of rules informally promulgated by federal agencies." "With increasing frequency, rules of general apphicability adopted by agencies informally . . . are being reviewed by [appellate and district] courts directly," before they are adjudicatively enforced or applied to a private party. ${ }^{2}$ The subject of this preenforcement judicial review, agency informal rulemaking, is a "quasi-legislative"s process which, in many respects, is widely considered superior to agency formal rulemaking and adjudication. ${ }^{4}$ The latter generally require the

THE FOLLOWING CITATIONS WILL BE USED IN THIS NOTE:

Recommendation 74-4: Preenforcement Judicial Review of Rules of General Applicability, in ADMINISTRATIVE CONFERENCE OF THE U.S., 1973-74 REPORT (1974) [hereinafter cited as Recommendation 74-4];

Committee on Judicial Review of the Administrative Conference of the U.S., Supporting Memorandum: Preenforcement Judicial Review of Rules of General Applicability (1974) [hereinafter cited as Support Memo];

Recommendation E: Preenforcement Judicial Review of Rules of General Applicability ('Transcript of Debate on 74-4, 1 lth Plenary Sess. of Administrative Conference 1974) [hereinafter cited as 74-4 Debate];

Verkuil, Judicial Review of Informal Rulemaking, 60 VA. L. Rev. 185 (1974) [heremafter cited as Verkuil].

1. Verkuil 185-86, See also White, Allocating Power Between Agencies and Courts: The Legacy of Justice Brandeis, 1974 DUKE L. J. 195, 235-42, comparing Davis, A New Approach to Delegation, 36 U. CHI. L. REv. 713 (1969), with Jaffe, The Illusion of the Ideal Administration, 86 HARv. L. REv. 1183 (1973).

2. Recommendation $74-4$, at 58. Such review takes place in three types of cases: (1) by an appellate court under a statute vesting it with power to review "orders" of specific agencies, e.g., Deutsche Lufthansa Aktiengesellschaft v. CAB, 479 F.2d 912 (D.C. Cir. 1973); City of Chicago v. FPC, 458 F.2d 731 (D.C. Cir. 1971), cert. denied, 405 U.S. 1074 (1972); (2) by an appellate court under a statute specifically providing for direct review of rules of general applicability promulgated by an agency in a manner substantially the same as outlined in 5 U.S.C. $\$ 553$ (1970), e.g., Occupational Safety and Healtli Act of 1970, 29 U.S.C. \& 655(f) (1970); Consumer Product Safety Act, 15 U.S.C. $\$ 2060$ (c) (1972); see e.g., Associated Indus., Inc. v. United States Dep't of Labor, 487 F.2d 342 (2d Cir. 1973); and (3) by district courts under their residual power to review agency action not otherwise reviewable, see, e.g., Abbott Laboratories, Inc. v. Gardner, 387 U.S. 167 (1967); Angel v. Butz, 487 F.2d 260 (10th Cir. 1973). For a general overview of these types of review, see Support Memo 1-2.

3. Amoco Oil Co. v. EPA, 501 F.2d 722, 735 (D.C. Cir. 1974).

4. See Wright, Court of Appeals Review of Federal Regulatory Agency Rulemaking, 26 AD. L. REv. 199, 201-02 (1974), citing K. DAvis, DisCRETIONARY JUSTICE-A Preliminary InQUiRY (1969). See generally $1 \mathrm{~K}$. Davis $\$ 6.01$. 
full panoply of trial-type procedures including a formal evidentiary record, ${ }^{5}$ while informal ruleinaking traditionally has required only notice, an opportumity to participate, and a "concise general statement" of the agency's basis and purpose for promulgating a rule. ${ }^{6}$ Moreover, informal rulemaking permits an agency to declare law prospectively, to invoke broader participation in the decision-making process, and to base a decision on a wide basis of information and agency-developed expertise. ${ }^{7}$ An agency is not limited, as it is in formal rulemaking and adjudication, to considering materials in an evidentiary record. ${ }^{8}$ The system is fair, flexible, and efficient. ${ }^{9}$ Yet, despite its advantages, the system is threatened because courts, frustrated with the sometimes onesided record presented to them by the agencies and confused over the appropriate standard to review that record, ${ }^{10}$ have on occasion imposed fornalizing procedures limiting the flexibility and utility of informal rulemaking. ${ }^{11}$

In a consideration of what standard of review is appropriate, particular conceptual and practical difficulties arise in connection with the use of the phrase "substantial evidence,"12 which appears in the judicial review provisions of a large number of statutes authorizing agency informal rulemaking. ${ }^{13}$ Different courts have treated the presence of the phrase "substantial evidence" in different ways. Some have construed this language in provisions authorizing judicial review of agency rules to mean a higher standard of review is required than when the phrase

5. 5 U.S.C. $\$ \S 556-57$ (1970). See notes 28-32 infra and accompanying text.

6. Id. $\$ 553$. See notes 26-27 infra and accompanying text.

7. See generally Wright, note 4 supra, at 201-02.

8. See generally id. See notes 38-54 infra and accompanying text.

9. See generally $1 \mathrm{~K}$. DAvIs, \$§ 6.01-.12.

10. Recommendation 74-4, at 1; Verkuil 185. See notes 38-54 infra and accompanying text.

11. See, e.g., Mobil Oil Corp. v. FPC, 483 F.2d 1238 (D.C. Cir. 1973); Chrysier Corp. v. Department of Transp., 472 F.2d 659 (6th Cir. 1972); cf. Industrial Union Dep't v. Hodgson, 499 F.2d 467 (D.C. Cir. 1974). In Industrial Union Dep't, the court noted that the Secretary of Labor had interpreted the "substantial evidence" language in the Occupational Safety and Health Act of 1970, 29 U.S.C. $\$ 655$ (f) (1970), as mandating the formalizing of informal rulemaking. 499 F.2d at 472 . In compliance with the Secretary's interpretation, he issued regulations prescribing that a "hearing" be held and an evidentiary record be developed so that a court could review them under the substantial evidence standard. Id. at 473. See 29 C.F.R. \$ 1911.15 (1974).

12. Synonymous phrases are "substantial evidence on the record as a whole" and "substantial evidence on a record."

13. E.g., Natural Gas Act, 15 U.S.C. \& 717r(b) (1970); Interstate Land Sales Full Disclosure Act, 15 U.S.C. \& 1710 (1970); Occupational Safety and Health Act of 1970, 29 U.S.C. $\S 655(f)$ (1970); Federal Coal Mine Health and Safety Act of 1969, 30 U.S.C. \& $816(\mathrm{~b})(1970)$. 
is not present, ${ }^{14}$ while others have held that the phrase adds nothing to the otherwise generally applicable arbitrary and capricious standard set out in the Administrative Procedure Act (APA). ${ }^{15}$ This confusion could be viewed as the normal pains of adjusting the meaning of the phrase "substantial evidence" from its traditional application in the review of a trial-type record produced in the formal evidentiary hearings which accompany formal rulemaking and adjudication ${ }^{16}$ to its use in the review of the non-adjudicatory type materials produced in the context of informal rulemaking. ${ }^{17}$ Persistent failure of the phrase "substantial evidence" to develop its own non-adjudicatory meaning within the informal rulemaking context, however, suggests a problem more basic than mere adjustment. That problem lias been informal rulemaking's failure to free itself from the confines of the adjudicative model since its formulation nearly thirty years ago. ${ }^{18}$ To date there is no clearly defined informal rulemaking model. As a result, the courts have not agreed upon an appropriate standard of review, and several standards have gained recent support resulting in a lack of con-

14. See, e.g., Consumers Union of United States, Inc. v. Consumer Prod. Safety Comn'n, 491 F.2d 810, 812 (2d Cìr. 1974) (dictum); Public Serv. Comm'n v. FPC, 487 F.2d 1043 (D.C. Cir. 1973), vacated and remanded on other grounds, 417 U.S. 964 (1974); Mobil Oil Corp. v. FPC, 483 F.2d 1238, 1262 (D.C. Cir. 1973); Chrysler Corp. v. Department of Transp., 472 F.2d 659 (6th Cir. 1972). See text acconpanying notes 51-54 infra.

15. 5 U.S.C. $\$ 706(2)$ (A) (1970); see, e.g., Associated Indus., Inc. v. United States Dep't of Labor, 487 F.2d 342, 350 (2d Cir. 1973) (Friendly, J.). See text acconupanying notes 47-50 infra.

16. One common definition of "substantial evidence" illustrates how closely tied the term has been to the adjudicative context. That definition is that "substantial evidence" is the amount of evidence whicl would justify a refusal to direct a verdict when there is a trial by a jury and the conclusion souglit to be drawn from the evidence by the jury is one of fact. Denver \& Rio Grande W. Ry. v. United States, 312 F. Supp. 329, 332 (D. Colo. 1970); Asbury v. United States, 298 F. Supp. 589, 592 (W.D. Va. 1969); First Citizens Bank \& Trust Co. v. Camp, 281 F. Supp. 786, 792 (E.D.N.C. 1968); Acne Fast Freiglit, Inc. v. United States, 281 F. Supp. 314, 318 (D. Del. 1968); Jones v. Celebrezze, 246 F. Supp. 701, 703 (D. Kan. 1965).

17. See, e.g., Synthetic Organic Chen. Mfg. Ass'n v. Brennan, 503 F.2d 1155 (3d Cir. 1974); Industrial Union Dep't v. Hodgson, 499 F.2d 467, 469 (D.C. Cir. 1974); Associated Indus., Inc. v. United States Dep't of Labor, 487 F.2d 342, 354 (2d Cir. 1973). In the Supporting Memorandum, it is stated that

[t]his has led to confusion, since "evidence," substantial or otherwise, is not a term that lawyers ordinarily use to describe unsworn submissions im informal rulemaking proceedings or undisclosed, unsworn material in agency files. None of such naterial, of course, has been tested by cross-examination. Moreover, the substantial evidence standard is usually considered applicable to agency findings of fact rather than broadly to "agency decisions." However, findings of fact typically are not nade in informal rulenraking proceedings. Support Memo 8 (footnotes omitted).

18. For an excellent discussion of this failure, see Verkuil 230-45. 
sistency and thoroughness in the depth and quality of judicial review. ${ }^{19}$

The Administrative Conference's ${ }^{20}$ Recommendation 74-4 seeks to remedy this situation by stating what materials should be included in an "administrative record" 11 for review by a court and by clarifying the standard for reviewing the adequacy of the factual basis of, and the rationality of, informally promulgated rules. ${ }^{22}$ The Recommendation defines the proper standard for reviewing an "administrative record" as the traditional arbitrary and capricious test of the APA. ${ }^{23}$ It gives this standard new meaning and bite, however, by applying it to an extensive but workable "administrative record" which will be presented to the reviewing court by the promulgating agency. ${ }^{24}$ If accepted by Congress and the judiciary, the suggestions in 74-4 will help to create a viable working model for judicial review of the informal rulemaking process that is both imdependent of its adjudicatory neighbor and responsive to the need for full and fair preenforcement review of informally promulgated rules.

This Note will explore and analyze Recommendation 74-4 and will describe the new and independent rulemaking model its acceptance will usher in. It begins with a comparison of informal and formal rulemaking and their respective traditional standards of review. It then surveys and analyzes the present review standards applied by different courts to informally promulgated rules of general applicability and discusses the ramifications of their application. This Note concludes with a discussion of the provisions of Recommendation 74-4. Special attention is given to the Recommendation's solution to the major problem plaguing informal rulemaking review today: how to

19. See White, supra note 1 , at 237-42. See notes 38-52 infra and accompanying text.

20. The Administrative Conference of the United States was established by the Administrative Conference Act, 5 U.S.C. $\$ \S 571$ et seq. (1970). The Conference consists of between seventy-five and ninety-one members including a full-time chairman appointed by the President for a five-year term, a representative from each indepeudent regulatory agency and executive department, attorneys, and scholars in administrative law. Its purpose is to "provide suitable arrangements through which Federal agencies, assisted by outside experts, may cooperatively study mutual problems, excliange information, and develop recommendations for actiou by proper authorities . . ." Id. § 571 . The Conference is empowered to make recommendations "to the President, Congress or the Judicial Conference of the United States." Id. $\$ 574$.

21. Recommendation 74-4, II 1, at 59; Support Memo 4-7. See text accompanying notes 77-86 infra.

22. Recommendation 74-4, TाT 2-4, at 59-60; Support Memo 7-10. See text accompanying notes 111-28 infra.

23. 5 U.S.C. $\$ 706(2)$ (A) (1970); Recommendation 74-4, at 60; 74-4 Debate 157.

24. See notes 77-80 infra and accompanying text, 
provide adequate review without destroying the effectiveness of informal rulemaking by fettering it with adjudicatory chains.

\section{STANDARDS OF REVIEW}

\section{The Administrative Procedure Act}

The APA, ${ }^{25}$ which provides for both informal and formal rulemaking and suggests the appropriate standards of judicial review in the absence of a contrary statutory provision, is the appropriate place to begin a brief examination of the rulemaking processes and the standards of review traditionally thought to be applicable to the different types of agency action. The informal rulemaking provisions of the APA merely require an agency to publish a notice of its proposed ruleinaking, to give interested parties an opportunity to participate, and to provide the court with a "concise general statement" of the agency's basis and purpose for promulgating the rule. ${ }^{26}$ Thus, only a certain minimum of information will be available to a count when it evaluates an agency's informal rulemaking. Although nowlere in the APA is it explicitly stated that informal rulemaking slould be reviewed under a certain standard, most authorities have regarded informal material produced in informal rulemaking as amenable only to the arbitrary and capricious review standard of the APA. ${ }^{27}$

In contrast, the formal rulemaking provisions of the APA demand that a more formal "liearing" procedure allowing for the development of factual evidence be utilized. ${ }^{28}$ "When rules are required by statute to be inade on the record after opportunity for an agency hearing,"29

25. 5 U.S.C. $\$ \$ 551$ et seq. (1970).

26. Id. $\S 553$. While there is no requirement in section 553 that an agency provide the reviewing court with anything more than its "concise general statement," the notice will be part of the public record and the parties can, theoretically, reach other information under the Freedom of Information Act, id. \$ 552 .

27. Id. $\S 706(2)(\mathrm{A})$. It is interesting to note that while there is no adjudicatory record created in informal rulemaking, the last sentence in section 706 of the APA requires a reviewing court to consider the "whole record or those parts of it cited by a party" when reviewing informal as well as formal rulemaking. This is particularly puzzling when it is noted that many courts which require a strict substantial evidence review of informal rulemaking do so ostensibly for the reason that "substantial evidence" demands a "record" and, therefore, infers a tougher review of more formal ruleinaking procedures. See, e.g., Chrysler Corp. v. Department of Transp., 472 F.2d 659 (6th Cir. 1972), where the term "record" in the National Motor Vehicle Safety Standards Act of 1966, 15 U.S.C. $\$ \S 1381,1394$ (a) (1970), led the court to apply a substantial evidence test under the reasoning of Citizens to Preserve Overton Park, Inc. v. Volpe, 401 U.S. 402 (1970).

28. 5 U.S.C. $\S \S 553,556-57(1970)$.

29. $I d . \S 553(\mathrm{c})$, 
representative procedural requisites, such as entitling the party to present his case by oral or documentary evidence, to submit rebuttal evidence, and to conduct such cross-examination as may be required for a full and true disclosure of the facts, are guaranteed..$^{30}$ Thus, a formal evidentiary record is mandated, and it is to be judicially reviewed according to the substantial evidence standard, ${ }^{31}$ a standard traditionally thought appropriate only when there is a formal adjudicatory-type record to review. ${ }^{32}$

Although there is even some confusion as to the appropriate scope of judicial review of informal rulemaking under the standards of the $\mathrm{APA},{ }^{33}$ that confusion is compounded when hybrid scopes of review are prescribed by an agency's organic statute. ${ }^{34}$ Depending upon the particular review language utilized in the organic legislation creating an agency ${ }^{36}$ or the otherwise applicable review provisions of the APA, and upon the particular court involved in review, ${ }^{36}$ the standard can

30. Id. §§ 556-57.

31. Id. $\S 706(2)(\mathrm{E})$.

32. See Industrial Union Dep't v. Hodgson, 499 F.2d 467, 468 (D.C. Cir. 1974); Associated Indus., Inc. v. United States Dep't of Labor, 487 F.2d 342, 354 (2d Cir. 1973); Support Memo 7-8.

33. Compare United States v. Allegheny-Ludlum Steel Corp., 406 U.S. 742 (1972) (limiting review of informal agency rulemaking to a rational basis test), with Citizens to Preserve Overton Park, Inc. v. Volpe, 401 U.S. 402 (1971) (stating in dictum that the substantial evidence test should be applied to section 553 informal rulemaking).

34. Compare Associated Indus., Inc. v. United States Dep't of Labor, 487 F.2d 342 (2d Cir. 1973) (Friendly, J.) (the rational basis test and the substantial evidence test tend to converge in the informal rulemaking context), with Public Serv. Comm'n v. FPC, 487 F.2d 1043, 1050 (D.C. Cir. 1973) (Leventhal, J.), vacated and remanded on other grounds, 417 U.S. 964 (1974) (not only is substantial evidence a stricter review standard than arbitrary and capricious but the presence of substantial evidence language in the review provisions of the Natural Gas Act, 15 U.S.C. $\S 717 \mathrm{r}(\mathrm{b})(1970)$, reflects an intent on the part of Congress to limit informal rulemaking procedures to a formal evidentiary record).

35. For analytical purposes, agency statutes which specifically provide for informal rulemaking review generally can be placed into one of three categories. Some statutes, e.g., Motor Vehicle Information and Cost Savings Act of 1972, 15 U.S.C. $\S \S 1901$ et seq. (Supp. II, 1972), defer to the review staudard of the APA; others, e.g., Consumer Product Safety Act of 1972, 15 U.S.C. §§ 2051 et seq. (Supp. II, 1972); Occupational Safety and Health Act, 29 U.S.C. $\$ \S 651$ et seq. (Supp. II, 1972), explicitly provide for substantial evidence review of informal rulemaking. Still others, e.g., Federal Hazardous Substances Act, 15 U.S.C. $\$ \S 1261$ et seq. (1970); Poison Prevention Packaging Act of 1970,15 U.S.C. $\S \S 1471$ et seq. (Supp. II, 1972), provide for both informal and formal rulemaking, with arbitrary and capricious review of informal rulenuaking and substantial evidence review of formal rulemaking.

36. See text accompanying notes 38-54 infra. Compare Superior Oil Co. v. FPC, 322 F.2d 601 (9th Cir. 1963), cert. denied, 377 U.S. 922 (1964) (the Ninth Circuit's application of the arbitrary and capricious test), with International Harvester Co. v. Ruckelshaus, 478 F.2d 615 (D.C. Cir. 1973) (the District of Columbia Circuit's appli- 
range from a fairly relaxed rational basis test to a severely restrictive substantial evidence test which requires an agency to add adjudicativetype procedures to its informal rulemaking. ${ }^{37}$ This confusion of standards is examined below.

\section{Present Preenforcement Review Standards}

Of all the review standards currently in vogue, the traditional arbitrary and capricious standard, as presently embodied in the APA, ${ }^{38}$ is the oldest and least stringent. ${ }^{39}$ A court utilizing the arbitrary and capricious standard, commonly called the "rational basis" test, considers informal rulemaking as a quasi-legislative process and proceeds to review the challenged rule as if it were reviewing only its constitutionality. ${ }^{40}$ Under this standard, a court approaches the informal rulemaking process with deference, asking only "whether on the factual premise upon which the [agency] acted, the rule promulgated is unreasonable, arbitrary, capricious or discriminatory."

cation of the same standard). Professor Verkuil suggests that a court's perception of the importance of a challenged rule can have a direct effect on the stringency of review. Verkuil 209.

37. See text accompanying notes 57-63, 67-70 infra.

38. 5 U.S.C. $\$ 706(2)$ (A) (1970).

39. In one of the earliest applications of this test, the Supreme Court noted that when dealing with "mixed questions of law and fact, the court confines itself to the ultimate question as to whether the [agency] acted within its power." ICC v. Umion Pac. Ry., 222 U.S. 541, 547 (1912). In a subsequent case, reviewing an FCC determination that the Rochester Telephone Corporation was controlled by another company and, therefore, was within the Coinmission's regulatory jurisdiction, the Supreme Court quoted an earlier opinion of Justice Cardozo, saying:

So long as there is warrant in the record for the judgment of the expert body

it must stand ... The judicial function is exhausted when there is found

to be a rational basis for the conclusions approved by the administrative body.

Rochester Tel. Corp. v. United States, 307 U.S. 125, 145-46 (1939), quoting

from, Mississippi Valley Barge Line Co. v. United States, 292 U.S. 282, 286-87

(1934).

40. Once a rational basis is found under this formulation, the courts refrain from further review of the rulemaking process. See e.g., United States v. George S. Bush \& Co., 310 U.S. 371 (1940); Rochester Tel. Corp. v. Umited States, 307 U.S. 125 (1939); Assigued Car Cases, 274 U.S. 564 (1927); Superior Oil Co. v. FPC, 322 F.2d 601 (9th Cir. 1963), cert. denied, 377 U.S. 922 (1964).

41. Superior Oil Co. v. FPC, 322 F.2d 601, 619 (9th Cir. 1963), cert. denied, 377 U.S. 922 (1964). See also United States v. Allegheny-Ludlum Steel Corp., 406 U.S. 742 (1972), where the Court affirmed certain car service regulations promulgated informally by the Interstate Commerce Commission pursuant to provisions of the Esch Car Service Act, 49 U.S.C. $\$ 1(14)$ (a) (1970). In its affirmance, the Court limited its review to the question of whether the Cominission's informal rulemaking was rationally supported. 406 U.S. at 749 . Whether this is the Supreine Court's final position on the proper standard of review is questionable, however, since the ICC's informal rulemaking procedures would probably have met a stricter standard if one had been imposed; moreover, cases involving agency action other than informal rulemaking suggest that $\cdot a$. 
and careful"42 standard of review also has been applied under the arbitrary and capricious language of the APA. ${ }^{43}$ In fact, the Court of Appeals for the District of Columbia in International Harvester Co. v. Ruckelshaus ${ }^{44}$ specifically has rejected the traditional rational basis test in favor of a tougher standard of review which will assure that agency informal rulemaking procedures provide "a framework for principled decision-making." 45 This reasoned decision-making standard requires a reviewing court to examine both the agency's decision and the facts on which that decision was premised. ${ }^{46}$

Two additional standards for the review of informal rulemaking have evolved from agency statutes which include "substantial evidence" language in their informal rulemaking review sections. The first of these tests may be classified as the "modest" substantial evidence test. ${ }^{47}$ It recognizes that the strict review connotation that the substantial evidence test carries in the adjudicatory situation should not carry over into the informal rulemaking context where no adjudicatory record exists. ${ }^{48}$ Rather, courts applying this modest substantial evidence review have noted that, in the review of informal rulemaking, the sub-

tougher standard may be forthcoming. See e.g., United States v. Midwest Video Corp., 406 U.S. 649 (1972); Citizens to Preserve Overton Park, Inc. v. Volpe, 401 U.S. 402 (1971); Sierra Club v. Froehlke, 359 F. Supp. 1289 (S.D. Tex. 1973). See generally Verkuil 206-07.

42. This language appears in City of Chicago v. FPC, 458 F.2d 731, 744 (D.C. Cir. 1971), cert. denied, 405 U.S. 1074 (1972), citing Citizens to Preserve Overton Park, Inc. v. Volpe, 401 U.S. 402 (1971).

43. 5 U.S.C. $\$ 706(2)$ (A) (1970).

44. 478 F.2d 615 (D.C. Cir. 1973).

45. Id. at 651 (Bazelon, J., concurring), quoting Environmental Defense Fund v. Ruckelshaus, 439 F.2d 584, 598 (D.C. Cir. 1971).

46. In International Harvester Co. v. Ruckelshaus, 478 F.2d 615 (D.C. Cir. 1973), the court reviewed the administrator's refusal to grant a one-year suspension of standards promulgated under the Clean Air Act, 42 U.S.C. $\$ 1857 f-1(b)(5)(D)$ (1970). The administrator, following a public hearing, had determined that the car manufacturers had failed to show that the technology necessary to meet the standards was unavailable. The court refused to apply the rational basis test to the administrator's decision, which constituted informal rulemaking; instead it applied a more searching standard which suggested that in certain limited circumstances cross-examination on a crucial issue might be necessary to achieve a reasoned decision. 478 F.2d at 615 .

47. See, e.g., Florida Peach Growers Ass'n v. United States Dep't of Labor, 489 F.2d 120 (5th Cir. 1974) ("substantial evidence" means to determine whether the agency carried out its essentially legislative task in a reasonable manner). See also Verkuil 226-30.

48. E.g., Deutsche Lufthansa Aktiengesellschaft v. CAB, 479 F.2d 912 (D.C. Cir. 1973), where the court held that the "record" requirement in the statutory informal rulemaking provision did not require that evidentiary facts be developed before review on an adjudicatory-type record, as in a fornnal rulemaking or judicial hearing, but rather required only that the agency proffer the comments and submissions made during the informal rulemaking proceedings to the reviewing court. 
stantial evidence test and the rational basis test "tend to converge." Proponents of this standard contend that an agency decision which is arbitrary and capricious must by definition be without substantial evidence in its support. ${ }^{50}$ In short, this test is effectively the same as the rational basis test. However, the tough close scrutiny connotation that substantial evidence carries in the adjudicative context has led other courts to conclude that the substantial evidence test as apphed to imformal rulemaking is a stricter standard of review than the arbitrary and capricious test. ${ }^{51}$ This tough-minded substantial evidence test requires a reviewing court to take a closer look at an agency's informal determination than does either the arbitrary and capricious test or the modest substantial evidence test, and it requires something more from an agency than traditional inforinal rulemaking. ${ }^{52}$ At the same time, this test, as do the others, acknowledges that an agency will define its own record for review..$^{53}$ Under this standard, the agency proinulgating a rule informally must show, based on a record which is more extensive than that required under arbitrary and capricious review, that substantial evidence supports its rule and not merely that its decision was not arbitrary and capricious. ${ }^{54}$

\section{Ramifications of the Review Standards}

A court which reviews an agency rule promulgated inforinally should insure that the agency's rule resulted from fair and reasoned decision-makmg ${ }^{55}$ and that the agency employed a procedurally sound, open, and discriminating informal proinulgation process. ${ }^{56}$ In seeking

49. Associated Indus., Inc. v. United States Dep't of Labor, 487 F.2d 342, 350 (2d Cir. 1973) (Friendly, J.); accord, Florida Peach Growers Ass'n v. United States Dep't of Labor, 489 F.2d 120, 128-29 (5th Cir. 1974); cf. Chenical Leaman Tank Lines, Inc. v. United States, 376 F. Supp. 508 (D. Del. 1973).

50. See L. JAFFE 602-04 (1965); Scala \& Goodman, Procedural Aspects of the Consumer Product Safety Act, 20 U.C.L.A.L. REv. 899, 933-36 (1973).

51. See Mobil Oil Corp. v. FPC, 483 F.2d 1238 (D.C. Cir. 1973). The court stated that "the Natural Gas Act term 'substantial evidence' sinacks of a judicial proceeding." Id. at 1262.

52. See id. What that something extra required is is less than clear from the opiniou, though it does require some record other than the agency's concise general statement. Cf. Canip v. Pitts, 411 U.S. 138 (1973).

53. Verkuil 224-25.

54. See note 64 infra. In Bownian Transp., Inc. v. Arkansas-Best Freight Sys., Inc., 95 S. Ct. 438 (1974), Justice Douglas, while discussing the disposition in the lower court, stated that a decision may be supported by substantial evidence and still reflect arbitrary and capricious action. Id. at 441.

55. Verkuil 230.

56. This does not mean adding formalizing procedures to informal rulemaking. Rather, it means that notice and comment rulenraking operates efficiently so as to maximize public input and rational agency decisionmaking. Id. 
to guarantee those goals, the courts should be wary of encumbering the informal rulemaking process with more formal, and hence less flexible, procedures. None of the standards of review currently being applied fully achieves these goals.

The rational basis test allows an agency to run an efficient rulemaking process. ${ }^{67}$ It places no fetters of consequence upon the agency and only requires it to make a decision that has some rational basis of support. ${ }^{58}$ A court reviewing an inforinally promulgated rule under this standard makes no examination into the factual premises underlying the agency's rule; rather, it assumes the proffered facts are true and determines on that assumption whether there is a rational basis for the rule. ${ }^{50}$ If there is, the rule is sustained..$^{60}$ No further attempt is made to review the facts which underlie the agency's rule, ${ }^{61}$ and agency good faith is assumed. ${ }^{62}$ Moreover, reliance upon agency expertise can run to extremes. ${ }^{63}$ Thus, the rational basis test allows only a cursory judicial check over agency abuse or grossly inappropriate decisions.

The reasoned decision test permits a more satisfactory judicial examination of botli the rule promulgated by the agency and the facts underlying the rule. ${ }^{64}$ It is a stricter standard than the rational basis

57. In this context, "efficient" means rulemaking which runs smoothly and reaches rational decisions with a minimum of effort. At the same time, however, the rational basis test provides a lazy agency with the opportunity to escape effective review by the manner in which it frames its "concise general statement."

58. Information which is presented to the agency but is not contained in the agency's concise general statement could be overwhelmingly against the agency's determination, while on the evidence before it-the agency's concise general statement-the reviewing court could find that the agency's determination is rationally supported.

59. "If the factual premise were itself open to review, then it would be necessary for all general rule-making to include a trial-like hearing . . . . [T] is is not required." Superior Oil Co. v. FPC, 322 F.2d 601, 619 (9th Cir. 1963), cert. denied, 377 U.S. 922 (1964).

60. We do not weigh evidence introduced before the Commission; we do not inquire into the wisdom of the regulations that the Commission promulgates, and we inquire into the soundness of the reasoning by which the Commission reaches its conclusions only to ascertain that the latter are rationally supported.

United States v. Allegheny-Ludlum Steel Corp., 406 U.S. 742, 749 (1972).

See generally Superior Oil Co. v. FPC, 322 F.2d 601 (9th Cir. 1963), cert. denied, 377 U.S. 922 (1964).

61. See Superior Oil Co. v. FPC, 322 F.2d 601, 619 (9th Cir. 1963), cert. denied, 377 U.S. 922 (1964).

62. This is implicit in a standard of review which scrutinizes the decision but not the rationality of the facts supporting the decision.

63. See note 106 infra and accompanying text.

64. The record compiled for review must be more complete for substantial evidence review than for arbitrary and capricious review. Consumers Union of United States, Inc. v. Consumer Prod. Safety Comm'n, 491 F.2d 810, 812 (2d Cir. 1974). See text accompanying note 46 supra. 
test, requiring not only a review of the rationale underlying the rule but also a review of the factual determinations which support the rule and were made during the rulemaking process. ${ }^{65}$ Still, it is the agency which selects and proffers the materials which the court reviews. Thus, without an affirmative duty to present a full and balanced picture of the information it considered, an agency can avoid effective review of both its rationale and the underlying factual basis by a careful selection and presentation of only supportive facts. ${ }^{66}$

The tough-minded substantial evidence test provides for a relatively more searching and thorough review. ${ }^{67}$ At the same time, however, this standard requires something new from the agency in the form of new procedures and new "reviewable record" materials. ${ }^{68}$ While requiring an agency to provide additional material to a reviewing court is not necessarily a bad thing for the informal rulemaking process, ${ }^{69}$ the requirement that traditional informal rulemaking techniques be burdened with additional formalized procedures in order to meet the substantial evidence test could inhibit the efficiency and effectiveness of the informal rulemaking process. ${ }^{70}$ In effect, this system of review creates a hybrid rulemaking, neither formal nor informal, a weak half sister to both.

While all the current review standards provide for at least some judicial scrutiny of agency action, all fail as truly effective standards

65. International Harvester Co. v. Ruckelshaus, 478 F.2d 615 (D.C. Cir. 1973). Judge Bazelon's concurring opinion recognizes that this reaction to the rational basis test may involve a cure which is worse than the ailment, namely "substantive evaluation of the Administrator's assumptions and methodology." Id. at 651. He prefers a "process" review in which the reviewing court reviews the adequacy of the informal ruleniaking process and avoids substantive review of the wisdon of the agency's factual and decisional determinations. Id. at 650-52.

66. There is no requirement that an agency present all the evidence for and against its rule. As such, its "concise general stateinent" in support of the rule can be expected to be just that, a concise general support statement. basis.

67. The rule must be supported by substantial evidence and not merely by a rational

68. See, e.g., Public Serv. Conım'n v. FPC, 487 F.2d 1043 (D.C. Cir. 1973), vacated and remanded on other grounds, 417 U.S. 964 (1974); Mobil Oil Corp. v. FPC, 483 F.2d 1238 (D.C. Cir. 1973); Chrysler Corp. v. Department of Transp., 472 F.2d 659 (6th Cir. 1972).

69. In fact, Recommendation 74-4 suggests that additional material in the form of an "administrative record" be required to be presented to a reviewing court. Recommendation 74-4, II 1 , at 59. See notes 77-86 infra and accompanying text.

70. "There is a danger that this engrafting of elements of the adjudicative model onto the rulemaking model will beconje a means of turning one [informal rulenlaking] into the other [formal rulemaking]." Verkuil 238; cf. K. Davis $\$$ 6.15, at 284 (Supp. 1970) (informal rulemaking is superior to formal rulemaking as a prospective decisionmaking device because it has no adjudicative on-the-record requirements). 
because they allow the agency to select and define those materials it tenders to a court for review. Without a standard record which presents to a reviewing court all sides of the relevant issues as they were presented to and considered by the agency, no court can insure an adequate and fair review, no matter how demanding the standard of review. This inadequacy arises from one of the inherent strengths of informal ruleinaking - an agency's consideration is not confined to inatters presented with full adjudicatory safeguards or upon a trial-type record. In fact, an agency in the process of informal rulemaking may consider materials, including its own expertise and unsworn testimony, none of which currently needs to be presented to a court for review. ${ }^{71}$ This flexibility in the informal rulemaking process nnakes judicial review difficult. Furthermore, there is presently no standard, representative administrative record which an agency must present to a court for review.

\section{RECOMMENDATION 74-4}

In response to the confusing array of informal rulemaking review standards presently being utilized and to the meffectiveness of these standards for purposes of judicial review, the Administrative Conference of the United States has recommended a model for preenforcement judicial review of rules of general applicability promulgated pursuant to informal rulemaking. ${ }^{72}$ This nodel requires an agency engaged in informal rulemaking to create an "administrative record" of certain materials it has considered, ${ }^{73}$ and it suggests that, notwithstanding the wording of an agency's organic statute directing substantial evidence or similar judicial review, the appropriate review standard is the traditional arbitrary and capricious test ${ }^{74}$ found in the review provisions of the APA. ${ }^{75}$

The Conference recognizes that since the agencies are not confined to an evidentiary record in inaking their decisions of what rules to promulgate, it is often unclear what information a court on preen-

71. See Verkuil 224; cf. $1 \mathrm{~K}$. Davis $\$ 7.06$, at 430.

72. Recommendation 74-4, at 58. The Recommendation is addressed to Congress, the Judicial Conference, and the many administrative agencies in the hope that its acceptance by these bodies will lead to a fair and responsible level of review by the reviewing courts without the necessity of changing the informal rulemaking process into a cumbersome or unattractive hybrid. Id.

73. Recommendation 74-4, đI 1, at 59; Support Memo 4; 74-4 Debate 152 (Verkuil).

74. Recommendation 74-4, โी 2-4, at 59-60; Support Memo 7-10; 74-4 Debate 155-60 (Verkuil).

75, 5 U,S.C. $\$ 706(2)(A)(1970)$. 
forcement review should demand in evaluating an agency's decision. ${ }^{76}$ It seeks to remedy this situation by suggesting the creation of an "administrative record"77 which, while not an "evidentiary record,"78 would be a recording of the information that the agency considered in its decision-making. The Recommendation delineates six types of material that should be included in this "administrative record": ${ }^{79}$

(1) the notice of the proposed rulemaking and any documents referred to therein; ${ }^{80}$

(2) the comments and other documents submitted by interested persons; 81

(3) transcripts of oral presentations made during the course of the rulemaking; 82

(4) "factual information" not included elsewhere that was "considered by the authority responsible ${ }^{83}$ for the proinulgation of the rule or that is proffered by the agency as pertinent to the rule"; 84

76. Support Memo 5; see Verkuil 224-25.

77. This term is used by Professor Verkuil. 74-4 Debate 154.

78. Support Memo 5.

79. The numbered provisions in the text correspond directly to the like numbered subsections of paragraph one of the Recommendation. Recommendation 74-4, at 59 .

80. Id. Notice of proposed rulemaking is already required by courts on review. 5 U.S.C. $\$ 553(1970)$. The supplying of documents referred to in the notice serves to give a more complete record of the notice given and, when those documents are part of a public record, to create a more convenient review record for the court. Support Memo 5. If notice is inadeqnate, then the enacted rule may be outside the proper scope of the proposed rulemaking since one of the functions of review is to determine if the agency considered all relevant cominents before making its determination. Verkuil 235. Inadequate notice is an independent ground for remand. See Wagner Elec. Corp. v. Volpe, 466 F.2d 1013 (3d Cir. 1972).

81. Recommendation 74-4, at 59. The Conference considers these to be a review "staple" and analogizes these documents to an evidentiary record in an adjudicatory setting. Support Memo 5.

82. Recommendation $74-4$, at 59 . This is not to suggest that oral presentations must or should be inade, but only that if they are made then they should be recorded for the aid of a reviewing court. Support Memo 5.

83. The language "considered by the authority responsible" is meant to limit the volume of information an agency must file under this subsection. The Committee's purpose under this provision is not to require unreasonable quantities and species of information from agencies which requirement could discourage the use of informal rulemaking. See Support Memo 15 n.12. See text accompanying notes 99-103 infra.

84. Recommendation $74-4$, at 59. This is the novel part of paragraph one. It removes an agency's power to define its own record and mandates that the agency provide the reviewing court with the information it relied upon. Support Memo 6. This mandate is directed to the problem created by an agency's present ability to defime its own review "record." For a discussion of this provision, see notes 91-110 infra and accoinpanying text. 
(5) reports of advisory committees; $;$ and,

(6) the agency's concise general statement or final order and any documents referred to therem. ${ }^{86}$

The remainder of the Recommendation advocates the application of a type ${ }^{87}$ of the rationally supported review standard to the "administrative record."88 Moreover, any substantial evidence language in the agency's authorizing statute is not to be imterpreted as implying that any particular procedures inust be followed by an agency during informal rulemaking ${ }^{89}$ in addition to those specified for traditional informal rulemaking in the APA. ${ }^{90}$

\section{Ramifications of Recommendation 74-4}

The requirement that an agency include in the inaterials presented to the court for review all "factual information [which was] considered by the authority responsible for promulgation of the rule" is perhaps the most important and innovative idea in the Recommendation. ${ }^{91}$ In effect, it requires the promulgating agency to compile and present to a reviewing court a representative record of the information it relied upon during the rulemaking, thus removing the agency's traditional power to define its own reviewable record. ${ }^{22}$ By requiring an

85. Recommendation $74-4$, at 59 . Some statutes provide for formally designated advisory committees. E.g., Color Additive Amendments of 1960, 21 U.S.C. § 346a (1970); Contract Work Hours and Safety Standards Act, 40 U.S.C. $\& 333$ (1970). This section requires the inclusion of their reports.

86. Recommendation $74-4$, at 59 . This coincides closely with the requirement of section 553(c) of the APA that an agency incorporate in its rule a concise general statement of its basis and purpose.

87. See United States v. Allegheny-Ludlum Steel Corp., 406 U.S. 742 (1972).

88. Recommendation 74-4, at 59-60. The Conference accepts the proposition advanced by supporters of the modest substantial evidence test, i.e., that the arbitrary and capricious and substantial evidence tests are essentially the same. Id. $\pi 3$, at 60 . The Recommendation adopts the arbitrary and capricious language in favor of the substantial evidence language to avoid the confusion surrounding the substantial evidence test as applied to informal rulemaking as to whether substantial evidence language requires "evidence" in the traditional adjudicatory sense and, therefore, requires some hind of adjudicatory procedures. Id. The Recommendation answers this question in the negative. Id.

89. $I d . ~ \pi 2$, at $59-60$.

90. 5 U.S.C. $\$ 553(1970)$.

91. Recommendation 74-4, $\pi 1$, pt. 4, at 59; Support Memo 5-6.

92. "It seems only proper that all significant and relevant factual information should be made available to the court on review." Support Memo 6. "[T] he Commission should be mandated to provide what it relied upon ...."74-4 Debate 153 (Verkuil). "[T]t is monstrous . . . to suppose that an agency should not tell the parties to the litigation or disclose to them everything they relied upon or considered to make the rule." Id. at 181 (Kramer). "[ [] t is incumbent upon us in (4) to make sure that the agency puts into the record on appeal the kind of material that should be available to the courts to consider, whether or not it hurts, whether or not it is material that has been rejected 
"administrative record" which presents materials both in favor of and in opposition to the agency's determination, ${ }^{93}$ the Conference has suggested the creation of a record which may, unlike its predecessors, ${ }^{94}$ actually subject informal rulemaking to a fair and adequate judicial review without changing informal rulemaking into a quasi-formal and less effective rulemaking process. ${ }^{95}$.

Under current informal rulemaking review standards there is no assurance that both sides contesting a rule will be fairly represented.98 Some courts have attacked the inherent unfairness of an agency-prepared administrative support document serving as a review record by implying that a "substantial evidence" or "whole record" requirement in an agency's organic legislation requires procedures in addition to those of traditional informal rulemaking. ${ }^{27}$ Such procedures, however, are patchwork and often decrease the effectiveness of the informal rulemaking process by requiring the addition of adjudicatory-type procedures to informal rulemaking. ${ }^{98}$ The Conference's "administrative

by the agency, not just to define the record as carefully as it can in its own favor." Id. at 187 (Verkuil).

93. It was proposed in debate, 74-4 Debate 177 (Auerbach), and rejected, id. at 187, that the Conference delete the section mandating agencies to create a two-sided record and to allow the parties to the review litigation to put before the court what they consider relevant. During the course of debate, Mr. Zener suggested the use of the Free. dom of Information Act, 5 U.S.C. $\$ 552$ (1970), as an alternative to a two-sided record. 74-4 Debate 184-85. It was thought by Conference members that a full and balanced record requirement was necessary out of principle and political necessity in light of congressional and judicial movements towards formalizing informal rulemaking. Id. at 181, 187 (Kramer and Verkuil). Though not expressly voiced, it seems apparent that the reason for rejecting a parties-create-the-record approach was that the record requirements were seen as an integral ingredient in the scope of the review requirement. Without the more complete record requirements, the arbitrary and capricious standard of review suggested in the Recommendation would be a less effective standard. The record and the review standards are inextricably bound. To allow a less than full administrative record would be to decrease the effectiveness of the rational basis standard of preenforcement judicial review.

94. See text accoinpanying notes 55-70 supra.

95. Such a quasi-formal process is exactly what one jurist thinks is required by "substautial evidence" language. Public Serv. Comm'n v. FPC, 487 F.2d 1043, 1053 (D.C. Cir. 1973) (Leventhal, J.), vacated and remanded on other grounds, 417 U.S. 964 (1974). See authorities cited in note 68 supra.

96. See note 58 supra.

97. Sucl procedures include the limited cross-examination suggested in International Harvester Co. v. Ruckelshaus, 478 F.2d 615, 630-31 (D.C. Cir. 1973). See also Thoinpson v. Washington, 497 F.2d 629 (D.C. Cir. 1973); Clirysler Corp. v. Department of Transp., 472 F.2d 659 (6th .Cir. 1972). But cf. Automotive Parts \& Accessories Ass'n v. Boyd, 407 F.2d 330 (D.C. Cir. 1968).

98. The best example is the judiciary's recommendation of cross-examination in limited situations. See International Harvester Co. v. Ruckelshaus, 478 F.2d 615, 630-31 (D.C. Cir. 1973). 
record" requirement attacks the problem of madequate review material directly, without adding adjudicative procedures to the non-adjudicative informal rulemaking process, and mandates the creation of a record capable of supporting an adequate review.

How extensive a record must an agency compile? Must everything that anyone in the agency looks at or listens to be included in the record? These and other questions were raised ${ }^{99}$ before the current "considered by the authority responsible" language was added to the Recommendation. ${ }^{100}$ The purpose for adding this language was twofold: first, to limit to a manageable size the material which an agency must present to a reviewing court; and second, to insure that material which was considered significant "by those whose thinking is of significance in the process" is included in the record. ${ }^{101}$ Apparently, something considered by someone such as an agency clerk or rejected by someone in the lower echelons of the agency need not be included. ${ }^{102}$ Where to draw the line, however, between those whose thinking is significant im the process and those whose thinking is not is a question left unanswered by the Conference. The language "considered by the authority" should probably be limited to the person or persons who actually render a decision in the form of a rule, but it could be read to include a larger class of persons depending on how broadly the word "authority" is defined. The failure of the Conference to delineate more clearly the breadth of material required for review leaves a reviewing court which adopts the Recommendation with a difficult problem of interpretation. However, it also leaves that court with a tool for increasing or decreasing the amount of material subject to review without altering the arbitrary and capricious standard. By imterpreting the word "authority" broadly, a court can fashion its review standard into a more searching review than would be possible on a narrower "administrative record" created by a narrower interpretation of the word "authority." In short, the word "authority" adds an element of flexibility to the "administrative record" so that it can be fitted to the particular procedures followed by a particular agency. It gives an anxious court a tool for mcreasing the intensity of factual review without the necessity of adopting a troublesome substantial evidence test. ${ }^{103}$

99. 74-4 Debate 178-80 (Zener).

100. Id. at 188.

101. Id. at 191 (Gellhorn).

102. Id.

103. See notes 111-28 infra and accompanying text. 
The Conference specifically states that the Recommendation takes no position with respect to an agency's use of its expertise in reaching a decision through informal rulemaking. ${ }^{104}$ Agency expertise has long been recognized as a valid, but not exclusive, tool of agency decisionmaking in the informal rulemaking context. ${ }^{105}$ Indeed, one of the strengths of agency rulemaking is the ability of an agency to acquire expertise and then to apply that expertise in future agency rulemaking. Where does Recommendation 74-4 stand on the expertise problem? Although the Recommendation inakes no specific inention of a solution to the problem, it does deal indirectly with some expertise problems through its "administrative record" requirements.

Improper use of agency expertise can be one method of avoiding effective judicial review of informal rulemaking. By relying heavily on its expertise, an agency has the ability to avoid effective review by removing some factual decision-making considerations from the reviewing court's vision. ${ }^{106}$ To counteract such an evasion, a reviewing court could demand to examine the reasons behind the applied expertise under the "considered by" language of Recommendation 74-4. ${ }^{107}$ Again a question of judicial imterpretation is raised. Material "considered by" could be read expansively to include explanations of agency expertise relied upon in the agency's determinations. Such an interpretation seems fair in view of the large role agency expertise can play in informal rulemaking and of the acknowledged need to provide for adequate review of rules promulgated thereby. This interpretation also would answer the fears of one Conference member that the "considered by the authority" language could require the recording of information and expertise which came to the authority's attention at any time and thus create an impractically large record. ${ }^{108}$ Assuming such a reasonable interpretation, this language would require that the presentation of factual information gatlered during the informal rulemaking process as well as an explanation of expertise the agency relied upon during the rulemaking under review be included in the "administrative record." 109 The rationale underlymg the expertise previously acquired and presently utilized by the agency should provide a

104. Support Memo 3.

105. $1 \mathrm{~K}$. DAvis $\$ 7.06$, at 429 .

106. See, e.g., Schwartz, Legal Restriction of Competition in the Regulated Industries: An Abdication of Judicial Responsibility, 67 HARv. L. REv. 436, $471-75$ (1954).

107. Recommendation $74-4$, $\Uparrow 1$, pt. 4 , at 59.

108. 74-4 Debate 184 (Collier).

109. This would be one kind of timing device suggested by Mr. Collier. Id. 
sufficient basis for review. ${ }^{110}$

The Conference further suggests that the rational basis standard be utilized in all preenforcement judicial review. ${ }^{111}$ This is a conscious rejection of the decisions of certain courts ${ }^{112}$ that the "substantial evidence" language appearing in some agency authorizing statutes ${ }^{113}$ connotes a subjectively tougher standard than arbitrary and capricious review ${ }^{114}$ - which tougher standard, in some instances, had been interpreted to mandate the use by an agency of adjudicative-type procedures. ${ }^{115}$ The Conference's suggestion recognizes the arbitrary and capricious standard of the $\mathrm{APA}^{116}$ as the most appropriate standard of preenforcement review for rules promulgated informally by administrative agencies. ${ }^{117}$ It also recognizes that while "substantial evidence" connotes a tougher review standard than "arbitrary and capricious" in the adjudicatory context, such a connotation should not carry over into the informal rulemaking context. ${ }^{118}$ Under the Conference's rea-

110. This is a practical solution which will insure reasoned decision-nnaking. Courts can require additional information if needed. Recommendation $74-4, \pi 1$, at 59.

111. Id. \โ 2-4, at 59-60.

112. See, e.g., Consumers Union of United States, Inc. v. Consumer Prod. Safety Comm'n, 491 F.2d 810, 812 (2d Cir. 1974) (dictum); Mobil Oil Corp. v. FPC, 483 F.2d 1238, 1262 (D.C. Cir. 1973).

113. See statutes cited in note 13 supra.

114. Recommendation $74-4, \pi 2$, at 59-60. See notes 51-54 supra and accompanying text.

115. The term "substantial evidence on the record as a whole," or comparable language, in statutes authorizing judicial review should not, in and of itself, be taken by agencies or courts as implying that any particular procedures must be followed by the agency whose actions are subject to the statute and, in particular, should not be taken as a legislative prescription that in rulemaking agencies must follow procedures in addition to those specified in 5 U.S.C. \& 553. Id. \2, at 59-60.

116. 5 U.S.C. $\$ 706(2)(A)(1970)$.

117. The appropriate standard for determining whether a rule of general apphcability adopted after informal rulemaking rests on an adequate foundation is stated in 5 U.S.C. \& 706(2) (A), which provides that a reviewing court must set aside action found to be "arbitrary, capricious [or] an abuse of discretion." Where such a rule is attacked on the ground that an asserted factual basis does not support it or that a necessary factual foundation is lacking, this standard requires a reviewing court to decide, in light of the information before it (imcluding the administrative materials described in paragraph 1), whether the agency's conclusions concerning the significance of factual information can be said to be rationally supported. Recommendation $74-4, \pi 3$, at 60 .

See also 74-4 Debate 157 (Verkuil).

118. Statutes providing for judicial review of rules adopted after informal rulemaking should refer only to the standards for review of such rules set forth in 5 U.S.C. \& 706, including the "arbitrary, capricious, [or] abuse of discretion" standard of Section 706 (2) (A) (but not including the "substantial evidence" standard of Section 706 (2) (E), which by its terms is inapplicable to such rules). Properly applied, those standards are adequate to ensure appropriate judicial scrutiny of rules adopted informally. Judicial review statutes that speak in terms of review according to the standard of "substantial evidence" should be construed as establishing a standard of review over informal rulemaking comparable to that set forth in Section 706 (2) (A), unless a contrary 
soning, the substantial evidence and arbitrary and capricious standards are effectively the same when applied to preenforcement informal rulemaking review. ${ }^{119}$ Moreover, the choice of the arbitrary and capricious test is an acceptance of rational basis review ${ }^{120}$ and a rejection of the concept that "substantial evidence" language in an orgamic statute requires procedures in addition to those of traditional informal rulemaking. ${ }^{121}$ In fact, when such language appears, the Recommendation suggests that its adjudicatory connotations be disregarded and that the arbitrary and capricious standard be applied.122 Simce the two standards are considered to be essentially the same, the "arbitrary and capricious" language which is unencumbered with adjudicatory connotations is preferable. ${ }^{123}$

But the rational basis test per se is not the Recommendation's standard. ${ }^{124}$ The Recommendation's test requires a full "administrative record," and as such it allows a quantitatively more thorough review than does the traditional rational basis test, which accepts the facts an agency chooses to submit. The conferenee's standard is more in line with the reasoned decision review presently used by some courts under the arbitrary and capricious rubric. ${ }^{125}$ The "reasoned decision" language is mentioned in the debate ${ }^{126}$ and can be used to summarize the Conference's view of the proper purpose of informal rulemaking judicial review. Simce the review contemplated by the Recommendation includes reviewing the factual foundations of the promulgated rule as well as the rationality of the rule, it resembles the reasoned decisionmaking review, which also looks at both the facts and the court's ration-

\footnotetext{
intent clearly appears. Recommendation $74-4, \pi 4$, at 60 .

See also 74-4 Debate 158 (Verkuil).

119. See Support Memo 9. See quotation in note 118 supra.

120. See quotation in note 117 supra. The rational basis test is discussed in notes 38-41 supra and accompanying text.

121. See quotation in note 115 supra. The tough-minded substantial evidence test is discussed in text accompanying notes 51-54 supra.

122. Recommendation 74-4, at 59-60; Support Memo 10. This is not true if the organic statute in which the substantial evidence language appears "clearly" expresses a contrary intent. Recommendation $74-4$, If 4, at 60 . Although the Conference never specifies what words would "clearly" express a contrary intent, it is evident that substantial evidence or comparable evidence is not, in and of itself, enough to express such a clear intent. See id. $\Uparrow 2$, at 59-60.

123. Recommendation $74-4, \mathbb{3} 3$, at 60 . For a full quotation of paragraph 3 , see note 117 supra.

124. Such a per se rational basis test is utilized in United States v. Allegheny-Ludlum Steel Corp., 406 U.S. 742 (1972). For a discussion of the per se test, see notes 3841 supra and accompanying text.
}

125. See notes $42-46$ supra and accompanying text.

126. $74-4$ Debate 157 (Verkuil). 
ale. ${ }^{127}$ However, it differs from that review in that it requires an agency to compile an "administrative record" to present to the court for both factual and decisional review, and it does not depend on an agency-selected support document to present the reviewable materials. ${ }^{128}$

In a separate statement accompanying the Conference's recommendation, Professor Davis raises a second substantial evidence question. Professor Davis argues that while the arbitrary and capricious standard is the proper test for reviewing the rationality of an informally promulgated rule, the tougher substantial evidence test should be applied when the review focuses upon a factual finding in support of the rule. ${ }^{120} \mathrm{He}$ cites in support Judge McGowan's recent opinion in Industrial Union Department $v$. Hodgson ${ }^{130}$ to the effect that "when the facts . . . are susceptable [sic] of being found in the usual sense, that inust be done, and the reviewing count will weigh them by the substantial evidence standard."131 Professor Davis' analysis contrasts the fact-finding element of rulennaking with its pure legislative judgment aspect. ${ }^{132}$ Further, he equates informal rulemaking fact finding with adjudicatory fact finding, the latter of which has traditionally been susceptible to substantial evidence review. ${ }^{133}$ The Conference rejected this suggestion, ${ }^{134}$ noting that "fact finding," as it is commonly understood, is a peculiarly adjudicative process designed to determine the truth or falsehood of particular facts whose determination enables

127. See text accompanying notes 64-66 supra.

128. See text accompanying notes 91-98 supra.

129. K. Davis, Recommendation E: Judicial Review of Agency Rulemaking 3 (undated statement, Adıninistrative Confereuce); 74-4 Debate 195-98.

130. 499 F.2d 467 (D.C. Cir. 1974).

131. Id. at 474; see Synthetic Organic Chem. Mfg. Ass'n v. Brennan, 489 F.2d 120 (5th Cir. 1974); cf. Amoco Oil Co. v. EPA, 501 F.2d 722 (D.C. Cir. 1974).

132. K. Davis, supra note 129 , at 6.

133. "The main difference in the two standards is that 'arbitrary and capricious' applies in the main to discretion, policy, and legislative judgment, whereas 'substantial evidence' applies in the main to findings of fact." Id. at 3; 74-4 Debate 194-97 (Davis). But see Industrial Union Dep't v. Hodgson, 499 F.2d 467 (D.C. Cir. 1974). There the court stated that

some of the questions involved im the promulgation of these standards are on the frontiers of scientific knowledge, and consequently as to them insufficient data is presently available to make a fully informed factual determination. Decision making must in that circumstance depend to a greater extent upon policy judgments and less upon purely factual analysis. Thus, in addition to currently unresolved factual issues, the formulation of standards involves choices that by their nature require basic policy determinations rather than resolution of factual controversies. Judicial review of inherently legislative decisions of this sort is obviously an undertaking of different dimensions. Id. at 474-75 (footnotes omitted).

134. See, e.g., 74-4 Debate 202, 212 (Gellhorn). 
a court to fit those facts into a predetermined law. ${ }^{135}$ This process involves testimony and cross-examination of witnesses to insure the truthfulness of the final fact determination, since once hardened, the facts will be fit into an existing law to determine the result of the case. Informal rulemaking involves a dissimilar process. ${ }^{136}$ Its central purpose is not to plug a determined fact into a predetermined law but rather to develop a rational and effective rule after a consideration of a wide basis of material. ${ }^{137}$ This process can be analogized to legislation in which a legislator (rulemaker) properly exercises a judgment and formulates a rule without having an evidentiary-type foundation of the sort which would readily yield to substantial evidence review. ${ }^{138}$ In short, informal rulemaking does not deal with specific findings of fact in an adjudicatory sense. It deals with them in a legislative sense, and therefore, review of factual issues in informal rulemaking may not rationally be subjected to the conventionally tougher substantial evidence review.

Pohcy reasons also argue against the application of the substantial evidence standard of review to the factual determinations underlying a rule, while applying the arbitrary and capricious standard to determine the rationality of a rule. Each rulemaking process involves the consideration of a countless number of separate factual issues; to require the application of adjudicatory procedures to each such issue would impose an impractically heavy burden which would either render informal rulemaking an inefficient and useless decision-making device or would so formalize informal rulemaking as to make it indistinguishable froin formal rulemaking. ${ }^{139}$ Either result could lead to the end of informal rulemaking and its attendant advantages. Additionally, arbitrary and capricious review on an "administrative record" seems

135. If an agency engages in such activity, then the substantial evidence test may be most appropriate. Id. at 206-07 (Auerbach).

136. Id. at 212-13 (Gellhorn).

137. See Amoco Oil Co. v. EPA, 501 F.2d 722 (D.C. Cir. 1974).

In rule-making . . . an agency's task is not to test raw evidence against a single, pre-established standard; rather the agency is to fashion a host of new legal standards-regulations-havimg prospective effect. A rule-making agency makes not one but dozens of "ultimate" decisions-not only because a set of regulations has many provisions, but also beeause adoption of any one provision constitutes a simultaneous rejection of many possible alternatives. Few if any of these "ultimate" decisions will depend on factual conclusions of the sort conventional in adjudication. Looking to the future, and commanded by Congress to make policy, a rule-making agency necessarily deals less with "evidentiary" disputes than with normative conflicts, projections from imperfect data, experiments and simulations, educated predictions, differing assessments of possible risks, and the like. Id. at 73435 .

138. 74-4 Debate 212-13 (Gellhorn).

139. Id. at 209, 213 (Verkuil, Zener). 
sufficient since rulemakers cannot be expected to be able to harden all the reasons and facts they rely upon in their rulemaking. Just as with legislators, a rulemaker will often have to make decisions on reasonable inferences and rational conclusions based on less than adjudicatorially verified information.

\section{CONCLUSION}

Recommendation 74-4 offers the best solution to date to the question of what should be the proper standard of preenforcement judicial review of informally promulgated rules of general applicability. Its solution is not simply a selection of arbitrary and capricious review over substantial evidence review. Rather, Recommendation 74-4 suggests a standard of review which is tougher than the traditional rational basis test per se while retaining the rational basis language. This retention of language is unfortunate simce it obscures the clarity of the Conference's solution to the real problem underlying the standard of review debate: how to increase the effectiveness of traditional arbitrary and capricious review without destroying the effectiveness of informal rulemaking as a legislative-type decision-making device. The Conference's solution is to create a flexible "administrative record" in order to provide the reviewing court with something it has heretofore lacked, nainely, an accurate and representative recording of the material which the agency considered in the promulgation of its rule. This should effectively increase the quality of review by providing the reviewing court with the raw material necessary to accomplish a thoroughgoing review. With this "administrative record" as a basis, the Recommendation's arbitrary and capricious test takes on new bite and becomes a review standard more capable than its traditional predecessor of providing effective review of informal rulemaking.

The "administrative record" suggestion provides a critical advantage over the tough-minded substantial evidence test as well. It does not require that burdensome adjudicative procedures be forced upon the informal rulemaking process. Such procedures effectively change the informal rulemaking process into a quasi-adjudicative process, decreasing its effectiveness as a legislative-type decision-making process by limiting its ability to consider wide varieties and sources of information. The Recommendation's "administrative record" approach, by contrast, is engineered to reflect the strengths of the informal rulemaking process (in much the same way an evidentiary record reflects the strengths of the adjudicative process) and to preserve the vitality of informal rulemaking with its varied channels of input. 